\title{
Upaya Meningkatkan Kompetensi Pedagogik Guru dalam Merencanakan dan Melaksanakan Pembelajaran Daring Melalui Supervisi Berkelanjutan
}

\author{
Riyo Darminto \\ SDN Wonokusumo VI/45 Surabaya \\ Jl. Wonosari Lor Baru No. 21 Kecamatan Semampir, Kota Surabaya \\ riyodarminto@gmail.com
}

\begin{abstract}
The main purpose of this action research is to determine the effect of continuous supervision on improving the pedagogic competence of teachers in Planning and Implementing Online Learning at SDN Wonokusumo VI/45 Surabaya. In addition, because there are other alternative actions, this action research also aims to determine the class teacher's teaching preparation and the suitability, accuracy and integration of the online learning plans that have been prepared. Online or online learning is considered a solution for teaching and learning activities to continue in the midst of the corona pandemic. Online learning is learning without face to face directly between teachers and students but is done online. Learning is done through video conferencing, e-learning, or distance learning. Although it has been agreed, this method is controversial. For teachers, the online learning system is only effective for assignments. They consider that to make students understand the material, the online method is considered difficult. The implementation of continuous supervision an effort to improve the pedagogic competence of teachers in Planning and Implementing Online Learning was carried out on 14 teachers at SDN Wonokusumo VI/45 Surabaya through a mechanism of 2 cycles, each of which used 11 effective school days. Cycle I, which was held on August 1-15, 2021, achieved 21\% completeness in the poor category, while in cycle II, which was held on August 16-31, 2021, it was able to achieve $100 \%$ cycle completion in the very good category. From these results, the authors convey that the implementation of continuous supervision is very effective in improving the pedagogic competence of teachers in Planning and Implementing Online Learning at SDN Wonokusumo VI/45 Surabaya. The increase in pedagogic competence is only limited to aspects of planning and implementing online learning and several other factors that influence besides continuous supervision are the quality of online learning plans, the existence of supporting school infrastructure and training.
\end{abstract}

Keywords: Competence, Pedagogy, Learning, Online, Supervision, Sustainable

\begin{abstract}
Abstrak
Tujuan utama dari penelitian tindakan ini adalah untuk mengetahui adanya pengaruh supervisi berkelanjutan terhadap peningkatan kompetensi pedagogik guru dalam merencanakan dan melaksanakan pembelajaran Daring di SDN Wonokusumo VI/45 Surabaya. Di samping itu, karena adanya alternatif tindakan lain, maka penelitian tindakan ini juga bertujuan untuk mengetahui persiapan mengajar guru kelas dan kesesuaian, ketepatan serta keterpaduan rencana pembelajaran daring yang telah tersusun. Pembelajaran dalam jaringan atau daring dianggap menjadi solusi kegiatan belajar mengajar tetap jalan di tengah pandemi corona. Pembelajaran daring merupakan pembelajaran tanpa tatap muka secara langsung antara guru dan siswa, tetapi dilakukan melalui online. Pembelajaran dilakukan melalui video conference, e-learning atau distance learning. Meski telah disepakati, cara ini menuai kontroversi. Bagi tenaga pengajar, sistem pembelajaran daring hanya efektif untuk penugasan. Mereka menganggap untuk membuat siswa memahami materi, cara daring dinilai sulit. Pelaksanaan supervisi berkelanjutan dalam upaya meningkatkan kompetensi pedagogik guru dalam Merencanakan dan Melaksanakan Pembelajaran Daring dilakukan pada 45 orang guru di SDN Wonokusumo $\mathrm{VI} / 45$ Surabaya melalui mekanisme 2 siklus yang masing-masing menggunakan waktu 11 hari efektif sekolah. Siklus I yang dilaksanakan pada tanggal 1 - 15 Agustus 2021 mencapai ketuntasan siklus $21 \%$ dengan kategori kurang, sedangkan pada siklus II yang dilaksanakan pada tanggal 16 - 31 Agustus 2021 mampu mencapai ketuntasan siklus $100 \%$ dengan kategori sangat baik. Dari hasil tersebut, maka penulis sampaikan bahwa pelaksanaan supervisi berkelanjutan sangat efektif dalam meningkatkan kompetensi pedagogik guru dalam Merencanakan dan Melaksanakan Pembelajaran Daring di SDN Wonokusumo VI/45 Surabaya. Peningkatan kompetensi pedagogik tersebut hanya terbatas pada aspek merencanakan dan melaksanakan pembelajaran daring dan beberapa faktor lain yang mempengaruhi selain supervisi berkelanjutan adalah kualitas rencana pembelajaran daring, adanya sarana prasarana sekolah yang menunjang dan pelatihan.
\end{abstract}

Kata kunci: Kompetensi, Pedagogik, Pembelajaran, Daring, Supervisi, Berkelanjutan 
Corresponding author: Riyo Darminto

Email Address: riyodarminto@gmail.com (Jl. Wonosari Lor Baru No. 21 Kec. Semampir, Kota Surabaya)

Received 09 September 2021, Accepted 06 October 2021, Published 19 November 2021

\section{PENDAHULUAN}

Pembelajaran dalam jaringan atau daring dianggap menjadi solusi kegiatan belajar mengajar tetap jalan di tengah pandemi corona. Pembelajaran daring merupakan pembelajaran tanpa tatap muka secara langsung antara guru dan siswa, tetapi dilakukan melalui online. Pembelajaran dilakukan melalui video conference, e-learning atau distance learning. Meski telah disepakati, cara ini menuai kontroversi. Bagi tenaga pengajar, sistem pembelajaran daring hanya efektif untuk penugasan. Mereka menganggap untuk membuat siswa memahami materi, cara daring dinilai sulit.

Meningkatnya angka persebaran virus corona di Indonesia mendorong pemerintah untuk mengeluarkan beberapa kebijakan atau langkah yang dapat dilakukan selama pandemi virus corona ini berlangsung, kebijakan kebijakan yang dilakukan dimaksudkan untuk menghindari adanya penyebaran virus corona pada siswa di berbagai sekolah atau perguruan tinggi. Beberapa kebijakan yang diambil antara lain adalah Ujian Nasional (UN) mulai dari tingkat Sekolah Dasar (SD), Sekolah Menengah Pertama (SMP), hingga tingkat Sekolah Menengah Atas (SMA) pada tahun 2020 resmi ditiadakan.

Karena itu, pihak Mendikbud meminta para guru dan siswa supaya bisa beradaptasi pembelajaran menggunakan sistem daring. Di satu sisi, ia menegaskan belajar dari rumah bukan berarti 100 persen diterapkan menggunakan sistem online. Ia menegaskan, pengumpulan tugas atau KBM bisa dilakukan dengan cara lain. Agar pendidikan bisa berfungsi dan mencapai tujuan seperti dirumuskan dalam undang-undang tersebut, maka pendidikan harus "diadministrasikan", atau dikelola dengan mengikuti ilmu administrasi. Yang paling sederhana, administrasi menurut Henry Fayol diartikan sebagai fungsi dalam organisasi yang unsur-unsurnya adalah perencanaan (planning), pengorganisasian (organizing), pemberian perintah (commanding), pengkoordinasian (coordinating), dan pengawasan (controlling) (Sagala, 2006: 23).

Dalam menyoroti salah satu peran guru dalam proses pembelajaran, yaitu sebagai perencana pembelajaran, setiap guru pada satuan pendidikan, termasuk Guru Kelas SD berkewajiban menyusun rencana pembelajaran daring yang lengkap dan sistematis agar pembelajaran efektif dan bermutu. Pembelajaran yang berlangsung secara efektif dan bermutu akan berimplikasi pada peningkatan mutu proses dan hasil belajar siswa.

Dengan memahami kondisi yang demikian, maka dipandang perlu adanya upaya peningkatan kompetensi pedagogik guru dalam Merencanakan dan Melaksanakan Pembelajaran Daring melalui supervisi berkelanjutan di SDN Wonokusumo VI/45.

Dari latar belakang yang telah dipaparkan di atas, dapat dirumuskan bahwa yang menjadi masalah dalam penelitian ini adalah: "Apakah supervisi berkelanjutan dapat meningkatkan kompetensi pedagogik guru dalam Merencanakan dan Melaksanakan Pembelajaran Daring di SDN 


\section{Wonokusumo VI/45?”}

Untuk meningkatkan kualitas hasil penelitian tindakan maka penulis perlu mempersiapkan alternatif-alternatif tindakan yaitu melaksanakan supervisi administrasi kelas, melaksanakan supervisi perangkat pembelajaran, dan melaksanakan pelatihan Perencanaan Pembelajaran Daring Tematik bekerja sama dengan Pengawas SD. Tujuan utama dari penelitian tindakan ini adalah untuk mengetahui adanya pengaruh supervisi berkelanjutan terhadap peningkatan kompetensi pedagogik guru dalam Merencanakan dan Melaksanakan Pembelajaran Daring di SDN Wonokusumo VI/45. Di samping itu, karena adanya alternatif tindakan lain, maka penelitian tindakan ini juga bertujuan untuk mengetahui persiapan mengajar guru kelas dan kesesuaian, ketepatan serta keterpaduan rencana pembelajaran daring yang telah tersusu

\section{Kompetensi Pedagogik}

Secara umum, kompetensi adalah seperangkat pengetahuan, keterampilan dan perilaku yang harus dimiliki, dihayati, dan dikuasai oleh suatu profesi dalam melaksanakan tugas keprofesionalannya (Undang-Undang Republik Indonesia Nomor 14 Tahun 2005 tentang Guru dan Dosen). Berkaitan dengan kompetensi profesi guru, Sagala mengemukakan sepuluh kompetensi dasar yang harus dimiliki guru, yaitu:
a. menguasai landasan-landasan pendidikan;
b. menguasai bahan pelajaran;
c. kemampuan mengelola program belajar mengajar;
d. kemampuan mengelola kelas;
e. kemampuan mengelola interaksi belajar mengajar;
f. menilai hasil belajar siswa;
g. kemampuan mengenal dan menterjemahkan kurikulum;
h. mengenal fungsi dan program bimbingan dan penyuluhan;
i. memahami prinsip-prinsip dan hasil pengajaran;
j. mengenal dan menyelenggarakan administrasi pendidikan

(Sagala, 2006: 210)

Kemudian Adapun Permendiknas RI No. 16 Tahun 2007 tentang Standar Kualifikasi Akademik dan Kompetensi Guru menyebutkan bahwa "Standar kompetensi guru ini dikembangkan secara utuh dari empat kompetensi utama, yaitu kompetensi pedagogik, kompetensi kepribadian, sosial, dan profesional. Keempat kompetensi tersebut terintegrasi dalam kinerja guru.” (BSNP, 2007: 8).

Pedagogi adalah art of teaching, seni atau strategi mengajar. Jadi kompetensi pedagogik adalah kemampuan mengelola pembelajaran siswa yang meliputi pemahaman terhadap siswa, perancangan dan pelaksanaan pembelajaran, evaluasi proses dan hasil belajar, dan pengembangan siswa untuk mengaktualisasikan berbagai potensi yang dimilikinya 
Upaya Meningkatkan Kompetensi Pedagogik Guru dalam Merencanakan dan Melaksanakan Pembelajaran Daring Melalui Supervisi Berkelanjutan, Riyo Darminto

\section{Konsep Pembelajaran Daring}

Peraturan Pemerintah Nomor 21 Tahun 2020 tentang Pembatasan Sosial Berskala Besar Dalam Rangka Percepatan Penanganan Corona Virus Disease 2019 (COVID-I9) (Lembaran Negara Republik Indonesia Tahun 2021 Nomor 91, Tambahan Lembaran Negara Republik Indonesia Nomor 6487) serta Peraturan Menteri Kesehatan Nomor 9 Tahun 2020 tentang Pedoman Pembatasan Sosial Berskala Besar Dalam Rangka Percepatan Penanganan Corona Virus Disease 2019 (COVID-19) (Berita Negara Republik Indonesia Tahun 2021 Nomor 326) memiliki implikasi besar dalam pendidikan, yaitu ditiadakannya pembelajaran langsung dan menggantinya dengan pembelajaran dalam jaringan (daring).

Pembelajaran daring memerlukan media pembelajaran yang variatif seperti media video pembelajaran yang terhubung ke youtube, media video conference, media jurnal ilmiah atau topik yang tersistem secara digital. Tetapi kemajuan teknologi pembelajaran harus didukung dengan sarana dan prasarana yang memadai, seperti meratanya jaringan internet ke sekolah-sekolah yang ada di pedesaan.

Pembelajaran daring membutuhkan tanggungjawab, kemandirian dan ketekunan pribadi, karena tidak ada yang mengontrol selain dirinya sendiri. Mereka harus mendownload dan membaca materi, menjawab quiz/soal serta mensubmit tugas secara mandiri. Kapabilitas pembelajaran online akan memberikan kinerja siswa yang lebih bagus dibanding dengan pembelajaran konvensional, karena selain berpengetahuan mereka juga melek teknologi (Hakiman, 2021).

Pembelajaran daring akan berjalan dengan baik apabila akses internet bisa menjangkau ke seluruh daerah, sehingga pendidikan secara online betul-betul dapat dinikmati oleh berbagai lapisan masyarakat. Pemerintah melalui Kemendikbud akan terus mendorong untuk diselenggarakannya pembelajaran online di berbagai instansi pendidikan negeri maupun swasta, sebagai langkah awal menyambut revolusi industri 4.0.

Secara proses, sebenarnya model pembelajaran daring ini sudah diatur dalam Permendikbud no. 22 tahun 2016 tentang Standar Proses dengan prinsip sebagai berikut:

1. Dari siswa diberi tahu menuju siswa mencari tahu.

2. Dari guru sebagai satu-satunya sumber belajar menjadi belajar berbasis aneka sumber belajar.

3. Dari pendekatan tekstual menuju proses sebagai penguatan penggunaan pendekatan ilmiah.

4. Dari pembelajaran berbasis konten menuju pembelajaran berbasis kompetensi.

5. Dari pembelajaran parsial menuju pembelajaran terpadu.

6. Dari pembelajaran yang menekankan jawaban tunggal menuju pembelajaran dengan jawaban yang kebenarannya multi dimensi.

7. Dari pembelajaran verbalisme menuju keterampilan aplikatif.

8. Peningkatan dan keseimbangan antara keterampilan fisikal (hardskills) dan keterampilan mental (softskills). 
9. Pembelajaran yang mengutamakan pembudayaan dan pemberdayaan siswa sebagai pembelajar sepanjang hayat.

10. Pembelajaran yang menerapkan nilai-nilai dengan memberi keteladanan (ing ngarso sung tulodo), membangun kemauan (ing madyo mangun karso), dan mengembangkan kreativitas siswa dalam proses pembelajaran (tut wuri handayani).

11. Pembelajaran yang berlangsung di rumah di sekolah, dan di masyarakat.

12. Pembelajaran yang menerapkan prinsip bahwa siapa saja adalah guru, siapa saja adalah siswa, dan di mana saja adalah kelas.

13. Pemanfaatan teknologi informasi dan komunikasi untuk meningkatkan efisiensi dan efektivitas pembelajaran.

14. Pengakuan atas perbedaan individual dan latar belakang budaya siswa.

\section{Supervisi Berkelanjutan}

Supervisi adalah salah satu tugas pokok dan fungsi kepala sekolah sebagai supervisor. Supervisi memiliki peran penting pada upaya pengawasan jalannya seluruh program sekolah yang telah direncanakan agar dilaksanakan sesuai dengan aturan dan target yang ada, baik secara periodik maupun dadakan. Dalam kaitannya dengan tugas pokok kepala sekolah, supervisi terdiri dari 5 jenis, yaitu supervisi kegiatan belajar mengajar, bimbingan dan penyuluhan, ko-kurikuler dan ekstrakurikuler, ketatausahaan, serta kerjasama dengan masyarakat dan dunia usaha.

Pada konteks supervisi berkelanjutan, seorang kepala sekolah berarti menjalankan fungsi supervisi kegiatan belajar mengajar dan bimbingan serta penyuluhan sekaligus. Hal ini dilakukan karena kegiatan belajar mengajar, khususnya yang berjalan secara daring adalah ujung tombak pelaksanaan pendidikan di sekolah, dan untuk memberikan hasil pendidikan sesuai dengan harapan maka supervisi berkelanjutan harus dilaksanakan. Makna berkelanjutan di sini lebih dititikberatkan pada bagaimana meningkatkan hasil pada satu periode ke periode berikutnya. Peran konsistensi di sini sangat diuji untuk membuktikan pelaksanaan suatu program berjalan agar tetap berjalan sebagaimana mestinya sesuai dengan aturan yang ada. Lebih dari itu, dengan adanya kontinuitas diharapkan hasil yang didapatkan akan semakin baik dan meningkat.

Apalagi dalam dunia pendidikan saat ini, inovasi pada model, metode dan strategi pembelajaran sangat dianjurkan penerapannya, sehingga konsep utama pada supervisi berkelanjutan semakin berkembang menjadi dorongan dan motivasi dari kepala sekolah kepada guru sebagai bawahannya secara struktural untuk menjadi pribadi yang senantiasa bermetamorfosis ke arah yang lebih baik. Dalam hal ini tentu saja dibutuhkan kerja sama yang baik antara kepala sekolah dengan guru, kepala sekolah dengan pengawas, dan pengawas dengan guru. Karena sebenarnya ketiga unsur inilah yang menjadikan supervisi berkelanjutan berhasil atau tidak, bertujuan atau tidak dan efektif atau tidak. 


\section{METODE}

\section{Setting Penelitian}

Menurut pengertiannya penelitian tindakan adalah penelitian tentang hal-hal yang terjadi di masyarakat atau sekelompok sasaran, dan hasilnya langsung dapat dikenakan pada masyarakat yang bersangkutan (Arikunto, 2002). Ciri atau karakteristik utama dalam penelitian tindakan adalah adanya partisipasi dan kolaborasi antara penulis dengan anggota kelompok sasaran. Penelitian tindakan adalah satu strategi pemecahan masalah yang memanfaatkan tindakan nyata dalam bentuk proses pengembangan inovatif yang dicoba sambil jalan dalam mendeteksi memecahkan masalah. Dalam prosesnya pihak-pihak yang terlibat dalam kegiatan teersebut dapat mendukung satu sama lain.

Sedangkan tujuan penelitian tindakan harus memenuhi beberapa prinsip sebagai berikut:

1. Permasalahan atau topik yang dipilih harus memenuhi kriteria, yaitu benar-benar nyata dan penting, menarik perhatian dan mampu ditangani serta dalam jangkauan kewenangan penulis untuk melakukan perubahan.

2. Kegiatan penelitian, baik intervensi maupun pengamatan yang dilakukan tidak boleh sampai mengganggu atau menghambat kegiatan utama.

3. Jenis intervensi yang dicobakan harus efektif dan efisien

4. Metodologi yang harus jelas, rinci dan terbuka, setiap langkah dari tindakan dirumuskan dengan tegas, sehingga orang yang berminat terhadap penelitian tersebut dapat mengecek setiap hipotesis dan pembuktiannya.

5. Kegiatan penelitian diharapkan dapat merupakan proses kegiatan yang berkelanjutan (on-going), mengingat bahwa pengembangan dan perbaikan terhadap kualitas tindakan memang tidak dapat berhenti tetapi menjadi tantangan setiap waktu. (Arikunto, Suharsimi, 2002: 82-83)

Sesuai dengan jenis penelitian yang dipilih, yaitu penelitian tindakan, maka penelitian ini menggunakan model penelitian tindakan dari Kemmis dan Taggart (dalam Arikunto, Suharsimi, 2002: 83), yaitu berbentuk spiral dari siklus yang satu ke siklus yang berikutnya. Setiap siklus meliputi planning (rencana), action (tindakan), observation (pengamatan), dan reflection (refleksi). Langkah pada siklus berikutnya adalah perencanaan yang sudah direvisi, tindakan, pengamatan, dan refleksi. Sebelum masuk pada siklus I dilakukan tindakan pendahuluan yang berupa identifikasi permasalahan.

\section{Subyek Penelitian}

Subyek penelitian tindakan ini adalah guru kelas dan guru mata pelajaran di SDN Wonokusumo VI/45 yang masih aktif pada tahun pelajaran 2021/2022 yang berjumlah 45 orang. Pelaksanaan penelitian dijadwalkan oleh penulis dengan rincian jadwal sebagai berikut:

Tabel 1. Waktu Pelaksanaan Tindakan

\begin{tabular}{|l|l|c|c|c|c|}
\hline \multirow{2}{*}{ No } & \multirow{2}{*}{ Jenis Kegiatan } & \multicolumn{4}{|c|}{ Bulan/Minggu } \\
\cline { 3 - 6 } & & Agt & Sep & Okt & Nop \\
\hline 1 & Konsultasi dengan pengawas. & M3 & & & \\
\hline
\end{tabular}




\begin{tabular}{|l|l|l|l|l|l|}
\hline 2 & Mengajukan proposal penelitian. & M4 & & & \\
\hline 3 & $\begin{array}{l}\text { Mengumumkan pengumpulan rencana pembelajaran } \\
\text { daring. }\end{array}$ & M4 & & & \\
\hline 4 & $\begin{array}{l}\text { Evaluasi kualitas rencana pembelajaran daring tahap } \\
\text { awal. }\end{array}$ & & M1-2 & & \\
\hline 5 & Revisi rencana pembelajaran daring. & & M2-4 & & \\
\hline 6 & $\begin{array}{l}\text { Evaluasi kualitas rencana pembelajaran daring tahap } \\
\text { akhir. }\end{array}$ & & M4 & & \\
\hline 7 & Konsultasi dengan pengawas. & & M4 & & \\
\hline 8 & Pelaksanaan dan evaluasi supervisi siklus I. & & & M1-3 & \\
\hline 9 & Pelaksanaan siklus II. & & & M4 & M1-2 \\
\hline 10 & Menyusun laporan tindakan. & & & & M3-4 \\
\hline
\end{tabular}

\section{Teknik Pengumpulan Data}

Pengumpulan data Penelitian biasanya dilakukan dengan menggunakan banyak cara dari berbagai sumber sehingga dikatakan bahwa pengumpulan datanya menggunakan triangulasi. Menurut Mills (2003:71), dari segi teknik pengumpulan data kualitatif, ada tiga teknik yang dapat dipilih oleh penulis untuk mengumpulkan data yaitu; (1) experiencing, pengumpulan data melalui pengalaman sendiri, terlibat dan berpartisipasi dalam kegiatan atau membuat catatan lapangan, (2) enquiring, pengumpulan data pertanyaan oleh penulis, dan (3) examining, pengumpulan data melalui pembuatan dan pemanfaatan catatan yang dapat berupa dokumen arsip dan jurnal.

\section{Validasi Data}

Validasi data juga dapat ditempuh dengan penganekaragaman alat pengumpul data. Semakin banyak data yang menguatkan didapat dengan alat pengumpul data yang berbeda maka data tersebut semakin valid. Sedangkan untuk memperoleh data yang mendukung keshahihan, serta sesuai denga fokus permasalahan dan tujuan yang hendak dicapai pada penelitian digunakan teknik validasi data.

Konsep validitas dalam aplikasinya untuk penelitian tindakan mengacu kepada kredibilitas dan derajat keterpecayaan dari hasil penelitian. Salah satu langkah dalam prosedur untuk mendapatkan derajat kepercayaan ialah melalui validasi, yang dalam penelitian kualitatif disukai dengan istilah verifikasi. Menurut Borg dan Gall (2003) terdapat lima tahap kriteria validitas, yaitu: validitas hasil, proses, demokratis, katalis, dan dialog.

Berdasarkan tahapan kriteria validitas, maka dalam penelitian ini validitas data menggunakan teknik Triangulasi Data. Triangulasi data yaitu mengecek keabsahan (validasi) data dengan mengkonfirmasikan data yang sama dari sumber yang berbeda untuk memastikan keabsahan (derajat kepercayaan).

\section{Teknik Analisa Data}

Pengumpulan data yang ada, selanjutnya dianalisis. Untuk menganalisis data tersebut, penulis memerlukan analisis data yang sesuai agar data yang diperoleh dapat dipertanggungjawabkan, maka 
dalam penelitian ini penulis menggunakan analisis data kualitatif dan analisis data kuantitatif. Analisis data kualitatif pada penelitian ini diperoleh dari hasil observasi yang dilakukan oleh penulis yang memuat gambaran tingkat kualitas Perencanaan Pembelajaran Daring dan implementasinya pada PBM setiap siklus.

Analisis data kuantitatif diperoleh dari nilai observasi pada kualitas Perencanaan Pembelajaran Daring dan implementasinya pada PBM yang bertujuan untuk mengetahui kualitas PBM dan efektivitasnya dalam pencapaian tujuan pembelajaran, di mana guru secara individu dapat dikatakan berhasil apabila sekurang-kurangnya mendapat nilai rata-rata 2,6 pada observasi Perencanaan Pembelajaran Daring dan implementasinya pada PBM.

Standar penentuan ketuntasan belajar siswa menurut Sudjana (2006:109) sebagai berikut:

$$
P=\underset{N}{\sum f} \times 100 \%
$$

Keterangan:

$\mathrm{P} \quad=\quad$ Persentase ketuntasan secara individu.

$\sum \mathrm{f}=\quad$ Jumlah nilai yang diperoleh guru.

$\mathrm{N}=\quad$ Nilai maksimal.

Sedangkan untuk mencari persentase keberhasilan tindakan menggunakan rumus:

$$
\mathrm{P}=\sum_{\mathrm{N}}^{\sum \mathrm{n}} \quad \mathrm{x} 100 \%
$$

Keterangan:

$\mathrm{P} \quad=\quad$ Persentase keberhasilan tindakan.

$\sum \mathrm{n} \quad=\quad$ Jumlah guru yang mendapat nilai 2,6.

$\mathrm{N}=$ Jumlah guru seluruhnya.

Data pengamatan dianalisis dengan menghitung rata-rata pada setiap siklus yang dilaksanakan, selanjutnya nilai rata-rata tersebut diklasifikasikan dengan kriteria sebagai berikut:

$4=$ Sangat baik.

$3=$ Baik.

$2=$ Cukup.

$1=$ Kurang.

\section{Indikator Kinerja}

Obyek penelitian tindakan ini adalah kompetensi pedagogik guru di SDN Wonokusumo VI/45 dalam menyusun dan Merencanakan dan Melaksanakan Pembelajaran Daring dengan indikator sebagai berikut: 
Tabel 2. Indikator Perencanaan Pembelajaran Daring

\begin{tabular}{|l|l|}
\hline No & \multicolumn{1}{|c|}{ Indikator yang Dinilai } \\
\hline 1 & Menentukan materi pembelajaran, alokasi waktu, KI dan KD. \\
\hline 2 & Menetapkan indikator pencapaian kompetensi. \\
\hline 3 & Menyiapkan presentasi materi. \\
\hline 4 & Menyusun kegiatan pembelajaran. \\
\hline 5 & Menentukan penilaian, media/alat, bahan dan sumber belajar. \\
\hline
\end{tabular}

Tabel 3. Indikator Pelaksanaan Pembelajaran Daring

\begin{tabular}{|l|l|}
\hline No & \multicolumn{1}{|c|}{ Indikator yang Dinilai } \\
\hline Kegiatan Pendahuluan \\
\hline 1 & Menyiapkan siswa secara psikis dan fisik untuk mengikuti proses pembelajaran. \\
\hline 2 & $\begin{array}{l}\text { Memberi motivasi belajar siswa secara kontekstual sesuai manfaat dan aplikasi } \\
\text { materi ajar dalam kehidupan sehari-hari. }\end{array}$ \\
\hline 3 & $\begin{array}{l}\text { Mengajukan pertanyaan-pertanyaan yang mengaitkan pengetahuan sebelumnya } \\
\text { dengan materi yang akan dipelajari. }\end{array}$ \\
\hline 4 & Menjelaskan tujuan pembelajaran atau kompetensi dasar yang akan dicapai. \\
\hline 5 & Menyampaikan cakupan materi dan penjelasan uraian kegiatan sesuai silabus. \\
\hline Kegiatan Inti \\
\hline 6 & $\begin{array}{l}\text { Melaksanakan aktivitas pembelajaran berorientasi pada tahapan kompetensi yang } \\
\text { mendorong siswa untuk melakukan aktivitas melalui proses afeksi yang dimulai } \\
\text { dari menerima, menjalankan, menghargai, menghayati, hingga mengamalkan. }\end{array}$ \\
\hline 7 & $\begin{array}{l}\text { Melaksanakan aktivitas mengetahui, memahami, menerapkan, menganalisis, } \\
\text { mengevaluasi, hingga mencipta. }\end{array}$ \\
\hline 8 & $\begin{array}{l}\text { Melaksanakan kegiatan mengamati, menanya, mencoba, menalar, menyaji, dan } \\
\text { mencipta. }\end{array}$ \\
\hline 9 & Mendorong siswa untuk melakukan proses pengamatan hingga penciptaan. \\
\hline 10 & $\begin{array}{l}\text { Melakukan pembelajaran yang menerapkan modus belajar berbasis } \\
\text { penyingkapan/penelitian (discovery/inquiry learning) dan pembela-jaran yang } \\
\text { menghasilkan karya berbasis pemecahan masalah (project based learning). }\end{array}$ \\
\hline 11 & $\begin{array}{l}\text { Melaksanakan seluruh kegiatan mengamati, menanya, pengumpulan data, } \\
\text { mengasosiasi, dan mengkomunikasikan. }\end{array}$ \\
\hline Kegiatan Penutup \\
\hline 12 & Melakukan refleksi dalam rangka evaluasi. \\
\hline 13 & Memberikan umpan balik terhadap proses dan hasil pembelajaran. \\
\hline 14 & $\begin{array}{l}\text { Melakukan kegiatan tindak lanjut dalam bentuk pemberian tugas, baik tugas } \\
\text { individual maupun kelompok. }\end{array}$ \\
\hline 15 & Menginformasikan rencana kegiatan pembelajaran untuk pertemuan berikutnya. \\
\hline
\end{tabular}

\section{HASIL DAN DISKUSI}

\section{Deskripsi Siklus I}

Supervisi siklus I dilaksanakan pada tanggal 1 - 15 Agustus 2021 dengan tanpa 
menginformasikan jadwal supervisi kepada masing-masing guru untuk mendapatkan efek dadakan. Pada siklus I ini penulis lebih fokus pada implementasi kegiatan inti dengan memperhatikan ramburambu pendekatan scientific yang meliputi 5 aspek kegiatan siswa. Pelaksanaan siklus I ini dilaksanakan secara tidak langsung karena penulis tidak terlibat dalam PBM secara langsung.

Kegiatan supervisi pada siklus I meliputi kegiatan supervisi administrasi perangkat pembelajaran dan supervisi pada masing-masing guru dengan beberapa tindakan sebagai berikut:

1. Mengevaluasi dokumentasi rencana pembelajaran daring.

2. Berdiskusi tentang merencanakan dan melaksanakan pembelajaran daring dengan masing-masing guru secara individual.

3. Supervisi dengan teknik observasi.

4. Menyerahkan hasil observasi pada masing-masing guru untuk evaluasi.

5. Revisi rencana pembelajaran daring (bila perlu).

6. Menyosialisasikan siklus berikutnya.

Setelah tahap supervisi administrasi, penulis melaksanakan supervisi dengan teknik observasi yang diawali pada guru yang dianggap penulis telah melengkapi administrasi pembelajarannya. Supervisi dilaksanakan 14 hari efektif sekolah dan pada tiap harinya hanya 2-3 guru yang disupervisi. Karena mempertimbangkan efektivitas hasil supervisi, penulis tidak melakukan koreksi langsung saat PBM berlangsung, akan tetapi beberapa catatan pada saat pengamatan penulis sampaikan pada saat PBM selesai dengan memanggil guru bersangkutan ke kantor KS untuk kemudian dilaksanakan revisi. Tindakan tersebut di atas penulis lakukan pada sebagian guru kelas 1, 2, 4 dan guru mata pelajaran. Evaluasi langsung penulis sampaikan kepada sebagian guru kelas 1 yang pada PBM tidak melaksanakan pendekatan scientific pada aspek mengamati. Hal ini tidak sesuai dengan karakter belajar siswa kelas 1 yang lebih dominan penggunaan media visualnya dari pada tekstualnya. Untuk sebagian guru kelas 2 dan 4 penulis lakukan evaluasi langsung karena tidak sesuai dengan rencana pembelajaran daring yang disusun dengan alasan kurangnya waktu, sehingga kegiatan refleksi tidak terlaksana pada PBM.

Khusus pada sebagian guru mata pelajaran, pada PBM sama sekali tidak melibatkan aktivitas psikomotorik siswa walaupun pada saat supervisi berlangsung materi yang disampaikan adalah materi tentang kesehatan, aktivitas psikomotorik harus disisipkan agar pembelajaran PJOK tetap relevan dengan indikator pencapaian kompetensinya yang meliputi aktivitas psikomotorik siswa.

Evaluasi dan revisi tidak banyak dilakukan pada guru kelas 3 dan 6 yang masih menerapkan kurikulum 2006, hanya pada kegiatan inti saja penulis menekankan pentingnya pendekatan scientific untuk memancing motivasi dan aktivitas belajar siswa. Sedangkan untuk guru PAI, PJOK, dan Bahasa Inggris penulis hanya mencatat minimnya aktivitas siswa dalam mempraktekkan apa yang didapat pada materi.

Secara garis besar pelaksanaan supervisi pada siklus I berjalan lancar dan ada kesesuaian antara rencana pembelajaran daring dengan PBM yang dilaksanakan sehingga efektivitas 
pembelajaran terasa. Khususnya pada sebagian besar kelas 6, pembelajaran terlaksana lebih kondusif dan antusiasme siswa terlihat karena sebagian besar guru kelas 6 menyediakan waktu yang banyak bagi siswa untuk melakukan aktivitas bertanya, berdiskusi, presentasi dan mendemonstrasikan beberapa hasil materi yang dianggap perlu.

Sedangkan di kelas online lainnya penulis masih belum menemukan aspek-aspek yang mendukung pembelajaran berjalan lebih kondusif. Akan tetapi kemungkinan untuk menjadi lebih baik penulis lihat masih ada karena adanya antusiasme para guru dalam melakukan seluruh instruksi dan hasil evaluasi yang penulis berikan. Untuk itu, sosialisasi pada siklus berikutnya penulis anggap perlu untuk memberikan kesempatan kepada masing-masing guru untuk mempersiapkan diri dan para siswanya sebelum supervisi dilaksanakan.

\section{Deskripsi Siklus II}

Supervisi siklus II dilaksanakan pada tanggal 16 - 31 Agustus 2021 dengan menginformasikan jadwal supervisi kepada masing-masing guru untuk memberikan kesempatan kepada guru bersangkutan agar merasa siap dalam melaksanakan PBM dan agar penulis mendapatkan bentuk paling ideal yang disajikan oleh guru dalam mengimplementasikan rencana pembelajaran daring. Pada siklus II ini penulis lebih fokus pada implementasi kegiatan inti dan penilaian autentik pada 3 aspek yaitu sikap, pengetahuan dan keterampilan. Pelaksanaan siklus II ini dilaksanakan secara tidak langsung karena penulis tidak terlibat dalam PBM secara langsung.

Kegiatan supervisi pada siklus II meliputi kegiatan supervisi administrasi perangkat pembelajaran dan supervisi pada masing-masing guru dengan beberapa tindakan sebagai berikut:

1. Mengevaluasi dokumentasi rencana pembelajaran daring.

2. Berdiskusi tentang merencanakan dan melaksanakan pembelajaran daring dengan masing-masing guru secara individual.

3. Supervisi dengan teknik observasi.

4. Menyerahkan hasil observasi pada masing-masing guru untuk evaluasi.

5. Penguatan dalam pembelajaran daring.

Setelah tahap supervisi administrasi, penulis melaksanakan supervisi dengan teknik observasi yang dengan urutan sebagaimana jadwal supervisi yang penulis informasikan pada masing-masing guru. Supervisi dilaksanakan 14 hari efektif sekolah dan pada tiap harinya hanya 2-3 guru yang disupervisi. Karena telah terjadwal secara tertulis, penulis melakukan koreksi langsung saat PBM berlangsung, dengan pertimbangan durasi yang cukup lama saat supervisi dilaksanakan, yaitu kurang lebih 2-3 jam pelajaran. Akan tetapi beberapa catatan pada saat pengamatan penulis sampaikan pada saat PBM selesai dengan memanggil guru bersangkutan ke kantor KS untuk kemudian dilaksanakan revisi.

Tindakan koreksi langsung penulis lakukan pada seorang guru kelas 3 dan seorang guru mata pelajaran. Koreksi langsung penulis sampaikan kepada seorang guru kelas 2 yang pada PBM tidak 
melaksanakan pendekatan scientific pada aspek menanyakan. Hal ini penulis temui setelah guru mendeskripsikan materi, guru langsung memberikan tugas kepada siswa tanpa jeda untuk bertanya jawab sebagai upaya untuk mengetahui tingkat pendalaman materi siswa. Teguran langsung juga penulis berikan kepada seorang guru mata pelajaran yang sekali lagi menyampaikan materi PJOK secara teori tanpa praktek dan aktivitas fisik.

Pada seluruh guru kelas 1, penulis hanya memberikan masukan untuk lebih banyak lagi menggunakan instrumen penilaian kinerja dari pada penilaian tertulis karena batas kemampuan siswa kelas 1 dan cakupan pembahasan materi yang diajarkan, sehingga revisi pada rencana pembelajaran daring perlu penulis sampaikan pada seluruh guru kelas 1 walaupun kesesuaian telah terlihat pada saat PBM. Evaluasi dan revisi tidak banyak dilakukan pada guru lainnya, hanya pada kegiatan inti saja penulis menekankan pentingnya pendekatan scientific untuk memancing motivasi dan aktivitas belajar siswa. Sedangkan untuk seluruh guru PAI, dan Bahasa Inggris penulis hanya mencatat minimnya aktivitas siswa dalam mempraktekkan apa yang didapat pada materi.

Secara garis besar pelaksanaan supervisi pada siklus II berjalan lancar dan ada kesesuaian antara rencana pembelajaran daring dengan PBM yang dilaksanakan sehingga efektivitas pembelajaran terasa. Khususnya di kelas 3, 4, 5, 6, dan PAI, pembelajaran terlaksana lebih kondusif dan antusiasme siswa terlihat karena para guru menyediakan waktu yang banyak bagi siswa untuk melakukan aktivitas bertanya, berdiskusi, presentasi dan mendemonstrasikan beberapa hasil materi yang dianggap perlu.

Adapun pelaksanaan penilaian pada masing-masing kelas perlu diupayakan untuk ditingkatkan melalui penelitian tindakan sejenis dengan variabel pelaksanaan kegiatan penilaian karena luasnya cakupan bidang untuk dinilai pada pelaksanaan kegiatan penilaian yang dilakukan oleh guru

\section{Diskusi}

Berdasarkan hasil supervisi berkelanjutan siklus I menunjukkan data tentang kualitas Perencanaan Pembelajaran Daring dengan rata-rata 2,6 dari poin maksimal 4 dengan persentase 65\% kategori cukup. Indikator dengan nilai tertinggi ada pada nomor 1 yaitu menentukan materi pembelajaran, alokasi waktu, KI dan KD dengan rata-rata 3,0 dan indikator dengan nilai terendah ada pada nomor 4 yaitu menyusun kegiatan pembelajaran dengan rata-rata 2,2. Dari 30 guru yang ada tidak ada satupun yang mendapat nilai rata-rata 3, yang tertinggi mendapat nilai 2,9 dan terendah mendapat nilai 2,0. Sedangkan yang mencapai target dengan nilai 2,6 atau lebih berjumlah 7 orang dan 23 orang lainnya masih di bawah target.

Kualitas Pelaksanaan Pembelajaran Daring dengan rata-rata 2,6 dari poin maksimal 4 dengan persentase $65 \%$ kategori cukup. Indikator dengan nilai tertinggi ada pada nomor 15 menginformasikan rencana kegiatan pembelajaran untuk pertemuan berikutnya dengan rata-rata 2,9 dan indikator dengan nilai terendah ada pada nomor 14 menyiapkan siswa secara psikis dan fisik 
untuk mengikuti proses pembelajaran dan 14 melakukan kegiatan tindak lanjut dalam bentuk pemberian tugas, baik tugas individual maupun kelompok dengan rata-rata 2,2. Dari 30 guru yang ada tidak ada satupun yang mendapat nilai rata-rata 3, yang tertinggi mendapat nilai 2,9 dan terendah mendapat nilai 2,0. Sedangkan yang mencapai target dengan nilai 2,6 atau lebih berjumlah 7 orang dan 23 orang lainnya masih di bawah target.

Kompetensi pedagogik guru dikatakan berhasil ditingkatkan apabila telah memenuhi $\geq 65 \%$ dari indikator penilaian kompetensi pedagogik atau rata-rata nilai 2,6. Sedangkan ketuntasan siklus tercapai apabila paling sedikit $75 \%$ guru telah memenuhi $\geq 65 \%$ dari indikator penilaian kompetensi pedagogik. Pada tabel 4.4 terlihat bahwa guru yang mencapai nilai minimal ketuntasan berjumlah 7 orang sehingga ketuntasan siklus hanya mencapai $21 \%$. Ketuntasan masih belum tercapai pada siklus I. Hal ini tidak membuat pesimisi penulis karena guru yang telah memiliki nilai hampir 2,6 berjumlah 15 orang atau $50 \%$. Untuk itu siklus II tetap berlangsung dengan metode tindakan serupa ditambah dengan hasil revisi siklus I dan konsultasi dengan pengawas.

Kemudian berdasarkan hasil supervisi berkelanjutan siklus II menunjukkan data tentang kualitas Perencanaan Pembelajaran Daring dengan rata-rata 3,1 dari poin maksimal 4 dengan persentase $77 \%$ kategori baik. Indikator dengan nilai tertinggi ada pada nomor 2 dan 3 yaitu menetapkan indikator pencapaian kompetensi dan Menyiapkan presentasi materi dengan rata-rata 3,4 dan indikator dengan nilai terendah ada pada nomor 4 yaitu menyusun kegiatan pembelajaran dengan rata-rata 2,8. Dari 30 guru yang ada hanya 6 orang yang mendapat nilai di bawah 3, yang tertinggi mendapat nilai 3,4 dan terendah mendapat nilai 2,6. Seluruh guru mencapai target dengan nilai 2,6 atau lebih.

kualitas Pelaksanaan Pembelajaran Daring dengan rata-rata 2,7 dari poin maksimal 4 dengan persentase 68\% kategori cukup. Indikator dengan nilai tertinggi ada pada nomor 2 dan 15 yaitu memberi motivasi belajar siswa secara kontekstual sesuai manfaat dan aplikasi materi ajar dalam kehidupan sehari-hari dan menginformasikan rencana kegiatan pembelajaran untuk pertemuan berikutnya dengan rata-rata 3,0 dan indikator dengan nilai terendah ada pada nomor 14 melakukan kegiatan tindak lanjut dalam bentuk pemberian tugas, baik tugas individual maupun kelompok dengan rata-rata 2,3. Dari 30 guru yang ada hanya 8 orang yang mendapat nilai di bawah 3, yang tertinggi mendapat nilai 3,4 dan terendah mendapat nilai 2,6.

Kompetensi pedagogik guru dikatakan berhasil ditingkatkan apabila telah memenuhi $\geq 65 \%$ dari indikator penilaian kompetensi pedagogik atau rata-rata nilai 2,6. Sedangkan ketuntasan siklus tercapai apabila paling sedikit $75 \%$ guru telah memenuhi $\geq 65 \%$ dari indikator penilaian kompetensi pedagogik. Pada tabel 4.7 terlihat bahwa semua guru telah mencapai nilai minimal ketuntasan yaitu berjumlah 45 orang sehingga ketuntasan siklus mencapai 100\%. Besarnya ketuntasan siklus II banyak dipengaruhi oleh kesiapan guru terhadap supervisi yang akan dilakukan oleh penulis sehingga secara administrasi dan pemahaman terhadap aspek-aspek yang dinilai dalam supervisi tersebut telah dipersiapkan sebelumnya. Selain itu, penulis juga perlu membuktikan adanya efektivitas pelaksanaan 
supervisi terhadap peningkatan kompetensi pedagogik dalam Merencanakan dan Melaksanakan Pembelajaran Daring. Hal ini dibuktikan dari rekapitulasi nilai kompetensi pedagogik guru yang meningkat pada pelaksanaan siklus II.

\section{KESIMPULAN}

Berdasarkan analisis data, dari penelitian ini dapat ditarik kesimpulan bahwa ada peningkatan kompetensi pedagogik guru dalam Merencanakan dan Melaksanakan Pembelajaran Daring di SDN Wonokusumo VI/45 melalui supervisi berkelanjutan. Peningkatan kompetensi pedagogik tersebut hanya terbatas pada aspek merencanakan dan melaksanakan pembelajaran daring dan beberapa faktor lain yang mempengaruhi selain supervisi berkelanjutan adalah kualitas rencana pembelajaran daring, adanya sarana prasarana sekolah yang menunjang dan pelatihan.

Dari kesimpulan tersebut penulis merekomendasikan agar guru seyogyanya sering memberi masukan kepada kepala sekolah atau sebaliknya tentang berbagai upaya untuk meningkatkan hasil pembelajaran siswa melalui pelengkapan sarana prasarana sebagai media pembelajaran atau kebutuhan pembelajaran lainnya. Selain itu, Kepala Sekolah harus secara aktif dan periodik melaksanakan supervisi karena selain telah menjadi tugas dan fungsi pokok kepala sekolah, supervisi juga terbukti mendorong guru untuk lebih meningkatkan kualitas PBM secara daring.

\section{UCAPAN TERIMA KASIH}

Terimakasih saya ucapkan kepada rekan kepala sekolah dalam komunitas seduluran saklawase dan Guru-guru di SDN Wonokusumo VI/45 Surabaya yang telah membantu peneliti dalam melaksanakan penelitian. Selain itu juga kepada seluruh stakeholder yang telah ikut berpartisipasi dalam melaksanakan penelitian ini.

\section{REFERENSI}

Arikunto, Suharsimi. 2002. Prosedur Penelitian. Yogyakarta: Rineka Cipta

BSNP. 2007. Peraturan Menteri Pendidikan Nasional Republik Indonesia Nomor 16 Tahun 2007 Tentang Standar Kualifikasi Akademik dan Kompetensi Guru. Jakarta: BSNP.

Mills, Geoffrey. 2003. Action Research: A Guide for the Teacher Researcher. New Jersey: Prentice Hall.

Peraturan Menteri Pendidikan Nasional Republik Indonesia Nomor 41 Tahun 2007 Tentang Standar Proses untuk Satuan Pendidikan Dasar dan Menengah.

Peraturan Pemerintah Nomor 19 Tahun 2005 tentang Standar Nasional Pendidikan.

Sagala, Syaiful. 2006. Administrasi Pendidikan Kontemporer. Bandung: Alfabeta.

Sudjana, Nana. 2009. Penelitian Tindakan Kepengawasan, Konsep dan Aplikasinya bagi Pengawas Sekolah. Jakarta: Binamitra Publishing.

Permendikbud Nomor 57 Tahun 2014 tentang Kurikulum 2013 SD/MI. 
Undang-Undang Republik Indonesia Nomor 14 Tahun 2005 tentang Guru dan Dosen.

Undang-Undang Republik Indonesia Nomor 20 Tahun 2003 Tentang Sistem Pendidikan Nasional. 